\title{
Computer Usage as Instructional Resources for Vocational Training in Nigeria
}

\author{
Nkasiobi S. Oguzor \\ Federal College of Education at Omuku, Nigeria
}

\begin{abstract}
The use of computers has become one of the driving forces in the delivery of instruction of today's vocational education and training (VET) in Nigeria. Though computers have become increasingly accessible resources for educators to use in their teaching activities, most teachers are still unable to integrate it in their teaching and learning processes. Computers are used to improve teaching quality where quality is very expensive to reproduce, or to substitute for the lack of teachers, or schooling opportunities that cannot be made available with conventional teaching methodologies. This paper examines the challenges of integrating ICT into instructional practices in VET and the barriers confronting implementation. Hence, the need for compatible computer education policies, suggestions to integrate ICT into teaching and learning practices are provided to assist the teachers to the use of computers in order to help the students acquire theoretical knowledge, grounded in real practice. It is the contention of this paper that though creating an ICT environment for teaching and learning in Nigeria may seem difficult, it would enhance students' achievement in vocational education and training.
\end{abstract}

Keywords: Instructional resources; Computer Usage; Information and communication technology; Vocational education and training

\section{Introduction}

In recent years, due to technological innovation, the use of information has intensified in industry. Information processing and electrical communication using computers have progressed remarkably, as office computers and word-processors are introduced at offices, and industrial robotics at factories. In our age, which is characterized by the importance of knowledge and computer, vocational education and training schools are responsible for the provision of qualified middle- level personnel mostly needed in industrial and service sectors. Thus, the provision of high quality computer and education at today's vocational education and training schools is very important. Around the world, all economically advanced democracies place a high value on the quality of their vocational education and training.

Vocational education or Vocational Education and Training (VET), also called Career and Technical Education (CTE), prepares learners for jobs that are based in manual or practical activities; traditionally non-academic and totally related to a specific trade, occupation or vocation. It is sometimes referred to as technical education, as the learner directly develops expertise in a 
particular group of techniques or technology. Vocational education and training has become a key policy issue as its importance to national economic performance has become generally recognized (Porter, 1990). In the face of rapid technological advances, economic globalization and the intensification of competition both within developed and developing countries, it is now clear that human resources are the key to continuing prosperity in the advanced economies. It is also clear to most governments, although to some perhaps more than the other that a maximum diffusion of education and training are necessary prerequisite for a healthy democracy and for maintaining a level of social cohesion and solidarity in fast changing pluralistic societies (Ruberti, 1993).

Despite the emergence of a common agenda for vocational education and training using computer across many countries, it is increasingly recognized that policy in practice varies significantly according to national contexts. Of course, it is one thing to develop grand visions of the vocational education and training society within official policy documents, translating such visions into reality usually turns out to be rather more problematic. This applies to the specific goals, cultural policies and initiatives that are being pursued and implemented, the wider institutional framework within which they take place, and the roles played by key actors such as state, employers and trade unions etc. By the same token, some countries may not only benefit from more favorable conditions for making progress towards the goal of vocational education and training but may already be some way further down this road than others with the aid of ICT.

\section{Vocational Education and Training in Nigeria}

Following an increased application of scientific technology, growing specialization of labor and an increasing connection between human skill and economic efficiency, the Nigerian education system is designed to integrate formal and non-formal modes of education delivery and to operate with flexibility creating abundant opportunities for career choice and development at every stage of life of the individual. Nigeria is fast evolving through the operation of its 6-3-3-4 education system from the year 1992; a 9-year compulsory basic education scheme was instituted. This means that education up to junior secondary is compulsory for all excluding pre- primary. This is to provide every child ample opportunities to benefit from educational provision designed to meet basic learning needs such as literacy, oral expression, numeracy, problem-solving, and general technical versatility. For this purpose, the curricula at both the primary and junior secondary levels comprise elements of general and vocational education in an increasing order of vertical complexity and intensity. At the completion of junior secondary education, only two options are available to students for further formal education; namely, a 3-year senior secondary or a 3-year technical college education. The curriculum at senior secondary level is designed to be both academic and vocational to provide further general education as well as prepare students for higher education and provide pre-professional exposure.

The formal tertiary institutions offer professional and technical education. They are conventional and technological universities, polytechnics, and colleges of education. Professional education and training is the province of universities through their various degree programs. Technical education is a concept reserved for the education of technologist and technician cadre of manpower in all occupational fields as offered by the polytechnics, monotechnics, and colleges of education. It is important to note that Nigeria maintains a unitary system of higher education with clear division 
of academic labor for the types of institutions involved. Thus, degree programs are offered only by institutions designated as universities whilst technologist and technician level programs are offered by polytechnics, monotechnics, and colleges of education. Professional bodies in the nonformal system collaborate with education institutions and relevant agencies in the design of appropriate curricula and in the maintenance of standards of training activities (Federal Ministry of Education, 1996).

Table 1. The Hierarchical Status and Roles of the Institutions in the National Education System

\begin{tabular}{|l|l|l|}
\hline $\begin{array}{l}\text { Education } \\
\text { Level }\end{array}$ & Institution Type & Primary Manpower Production Role \\
\hline Tertiary & University & Professionals (i.e. high level manpower) \\
\hline & Polytechnic/Monotechnic & $\begin{array}{l}\text { Technologist and technician (i.e. middle level } \\
\text { manpower) }\end{array}$ \\
\hline & $\begin{array}{l}\text { College of Education } \\
\text { (Technical) }\end{array}$ & $\begin{array}{l}\text { Technician level technical teachers (i.e. middle level } \\
\text { manpower) }\end{array}$ \\
\hline Secondary & Technical College & $\begin{array}{l}\text { Craftsmen and master craftsmen (i.e. low level } \\
\text { manpower) }\end{array}$ \\
\hline Post Primary & BEST Centre & Operatives and artisans (i.e. low level manpower) \\
\hline Primary & Primary School & Basic education \\
\hline
\end{tabular}

Table 2. The Enrolment in Nigerian Secondary and Vocational Technical Colleges (1991-2001)

\begin{tabular}{|c|c|c|c|c|}
\hline Year & $\begin{array}{r}\text { Number of } \\
\text { secondary } \\
\text { schools }\end{array}$ & Enrolments & $\begin{array}{r}\text { Number of } \\
\text { technical } \\
\text { colleges }\end{array}$ & Enrolments \\
\hline 1991 & 3,854 & $1,653,891$ & 208 & 46,083 \\
\hline 1992 & 5,840 & $1,814,000$ & 202 & 40,878 \\
\hline 1993 & 5,948 & $1,865,189$ & 190 & 72,136 \\
\hline 1994 & 6,092 & $2,794,498$ & 300 & 72,136 \\
\hline 1995 & 5,991 & $2,934,349$ & 240 & 76,434 \\
\hline 1996 & 5,859 & $2,941,781$ & 252 & 89,536 \\
\hline 1997 & 6,001 & $2,923,791$ & 261 & 1,179 \\
\hline 1998 & 5,860 & $2,901,993$ & 261 & 1,426 \\
\hline 1999 & 6,008 & $3,123,277$ & 261 & 1,425 \\
\hline 2000 & 6,009 & $3,600,204$ & 261 & 1,835 \\
\hline 2001 & 5,959 & $4,032,083$ & 261 & 1,835 \\
\hline
\end{tabular}

Source: Compiled from Social Statistics in Nigeria 1995; Annual Abstracts of Statistics 2001; Federal Office of Statistics; Nigeria. 


\section{Level of ICT on Vocational Education and Training}

When generally compared with the developed countries (IES, 2006), the educational uses of ICT on vocational education and training schools in Nigeria are still in the infancy stage. Most learners are taught by the traditional approach and often with the resultant effect of poor performance. Computer assisted learning provides the active participation and hands-on-experience that learners require to construct meaningful learning. The use of computers has been associated with improvements in people's education, labor market prospects, and everyday lives. Since the use of computers help students gain computer literacy, use rates may indicate how well prepared the current generation of students will be to enter a workforce where computer literacy is in demand. However, national cultures have effect on student's attitudes and usage. Students have different experiences of the computer, hold different attitudes toward the computer, have different opinions on how the computer will affect society and their own lives, and use it themselves differently.

While educators tend to integrate and implement computer games in VET having educational characteristics within educational settings, approximately half of the students do not have any chance in order to use computers. The number of computers installed in the schools is deficient, considering access to computers; one computer is shared on average as many as 50 students. Budgets for computers at vocational education and training schools are usually allocated by the prefectural government, in which the manufacturers and types of hardware and software to be purchased are determined and imported. Many hardware manufacturers and software developers compete with one another, and incompatibility is always a problem. This pattern limits the exploration of the full potential of computers, and the extent to which they can influence learning. To be economically feasible and reach economies of scale, software must be "tamed" and adapted to the ongoing needs of schools and teachers, and must fit within the constraints of existing curricula and subject-matter fragmentation. Consequently, countries at different levels of economic, industrial, and educational development will have different needs.

The installation and cost of computers in schools are financed by the government budgets and subsidies from the Ministry of Education. As to the objective of the educational use of computers in vocational education and training, the priority was put on understanding the computer itself, followed by training the students' ability to collect, analyze and process information, developing ability to solve problems and to consider analytically, and to motivate students study. Fascinated with the means and flabbergasted ends, politicians, educational planners, educators and computer experts are puzzled by the possibilities of the technology. Although official rhetoric and plans are very ambitious, resources allocated for these projects are very limited. Moreover, broad policies are commonly established in the absence of convincing evidence about the potential benefits and the actual effects of introducing computers in schools (Oliveira, 1998).

As a consequence, Nigeria can no longer afford to ignore the technological revolution but have to put on the agenda the development of new technologies and their own development using two approaches, via internal technological revolution and the absorption and efficient application of new technologies from abroad. This pattern of technology innovation in schools inhibits its full adoption, where innovations need to be justified by considerations of their costs and benefits. This pattern limits the exploration of the full potential of technologies, and the extent to which they can influence the teaching and learning of vocational education and training courses. Indeed, the 
level of the computer and ICT in vocational education and training courses is affected based on the nature, intensity, and characteristics of the utilization of the technology.

What makes the Nigerian case interesting is not simply that Nigeria has encountered difficulties in attempting to further progress the cause of using computers and ICT in their vocational education and training, but that its experience may also be instructive as to the kind of challenges that other developing countries may encounter. The challenge for politicians and decision makers in a number of developing countries is to reconcile their personal preferences for the new technology, the pressures to respond to labor markets, the need to respond to the society's aspirations, and the anxieties provoked by automation with the provision of effective conditions for the use of computers in schools. The speed and pervasiveness with which microcomputers have been introduced throughout the world probably confirms that the politicians' instincts are correct. At the same time, educators feel that schools would lose even more of their already eroded legitimacy if they failed to adapt themselves to the technological and social changes brought by the impact of computer technology (OECD/CERI-Center for Education Research and Innovation 1986). In this, extravagant computer and ICT education policies, however, divert scarce resources from already impoverished educational systems.

\section{Instructor Competence}

As numerous developments in technology are affecting vocational education and training, the traditional ways of teaching and learning are changing. The traditional ways of teaching only appeals to a small minority of learners. The traditional classroom environment can often neglect factors that are essential for learning. Presently in Nigeria, most learners are taught by the traditional approaches which often place the learners in a passive role. Teachers are therefore compelled by the learner heterogeneity to provide alternative units of instruction and alternative strategies to enable the students to attain educational objectives at their own rate. But the self efficacy expectations mediate the actual involvement in a particular teaching process. Before a teacher can be expected to use computer and ICT to impact knowledge or learn the skills for producing software, it is necessary that such a teacher know and is competent in the usage. Training teachers as computer instructors is an urgent and essential matter. Since most software has to be developed by the teachers themselves, intensive training should be requested. Computers are excellent tutorial tools, and they help teachers to become more efficient and effective for teaching, but they cannot replace teachers. Hiring special instructors for computers should be considered

Furthermore, at epileptic stage, they are increasing teachers' workloads. Computer and ICT will be adopted only if perceived by teachers as making sense and being advantageous in their work. Though some guidelines and priorities are essential, flexibility is necessary to foster creativity, experimentation, and innovation approaches. In that sense, the effort of UNESCO (2009), in setting up norms of competences in ICT for teachers is understandable, and was given at the conference Moving Young Minds, and set three approaches to improve the quality of education, reduce poverty and inequity, advance the standards of living, and prepare a country's citizens for the challenges of the 21st century. 
- Increasing the technological uptake of the workforce by incorporating technology skills in the curriculum-or the technology literacy approach

- Increasing the ability of the workforce to use knowledge to add value to economic output by applying it to solve complex, real-world problems- or the knowledge deepening approach

- Increasing the ability of the workforce to innovate and produce new knowledge and of citizens to benefit from this new knowledge- or the knowledge creation approach

The use of computer and ICT simulations to replace expensive equipment in vocational education and training schools can also be a cost effective application and an important means to secure equal access to education and to equal quality. In vocational schools this is relatively easy because teachers are highly motivated for vocational education and are flexible to respond to contemporary social needs. Besides, many of them used to be engineers or to work in business and have well-developed computer and ICT knowledge and skills, so they are positive about using them. On the contrary, many teachers also have not integrated computers and ICT or used these tools to supplement instruction (Bauer \& Kenton, 2005). Bennett (2002) questioned whether schools would ever implement the potential for learning that computers and ICT offer. He argued that more effective education would result only if citizens, educators, parents, and politicians understand how computers could be used in schools effectively and software developers would create useful software: until schools can permit a major alteration in the way teaching is carried on, they must necessarily continue to miss out on the improvement that computer technology can bring.

\section{Course Structure}

Countries throughout the world regard ICT as a core component for learning (Anderson \& Van Weert, 2002). The use and integration of computers and ICT in vocational education and training provide students with important skills applicable to computer related tasks. To be introduced in schools of vocational education and training, software must be adapted to the curriculum. The more it deviates from the concrete needs of programs and teachers, the less likely it is to be implemented, regardless of its quality or degree of innovativeness. Ignoring the needs of teachers and the dynamics of schooling introduces a risk similar to what happened to instructional television. By denying the importance of television as a teaching/learning tool, educators failed to produce interesting programs.

Responding to the real needs of schools and trying to avoid the past errors of ignoring teachers' viewpoints (Dieuzeide, 1986), private software providers are offering not only specific courseware tailored to curricula but are also preparing teachers' guides for general purpose software within the typical classroom mode, using teacher-led instruction. To be economically feasible and reach economies of scale, software must be "tamed" and adapted to the ongoing needs of schools and teachers, and must fit within the constraints of existing vocational education and training curriculum as well as subject-matter fragmentation. Despite such limitations, there is room for creativity, and positive responses are already emerging. This is the pattern most likely to be followed for the utilization of computers in Nigeria. Hence, the need to choose curriculum- 
relevant software to maximize the learning gains and to increase school quality is appearent. Software can be made teacher-proof in the technical sense that they would compensate for weaknesses of teachers and provide norms and standards which most poorly trained teachers could not achieve. Otherwise, computers and ICT would only mean an additional cost. Moreover, in the teaching and learning of vocational education and training courses if software were not directly related to its curricula but used to enhance general intellectual capacities or thinking habits only as some would prefer. It would be primarily used outside the school context by students from wealthier homes, thus increasing inequity.

Moreover, a constraint for software acquisition or production is the availability of hardware and the degree of standardization within school systems. Software in itself is useless unless three basic conditions are simultaneously satisfied: teacher involvement, curriculum fitness, and the establishment of level technological support. The limited resources suggest the need to design selective computer and ICT education policies. Priorities should follow from realistic analysis of the economic and industrial environment, as well as from the characteristics of the educational system. Computers, as other technologies, may be more effective when related to pressing problems, used to deal creatively with major deficiencies of educational systems, or aimed at the needs of individual learners that cannot be adequately met with conventional means.

\section{ICT Impact on Vocational Education and Training}

The introduction of ICT on vocational education and training provides various opportunities in teaching and learning which helps not only to produce, access information but also to facilitate the transfer and acquisition of knowledge. The introduction of computers, which is the major and most influential technology of the last millennium, has however made the impact of technology greater felt in every sector and also in the educational sector. It is through the introduction of this major technology that the world actually started talking about information technology (Oguzor, et al, 2010). Globalization and the use of ICT in vocational education and training are leading to a new qualitative and quantitative way of learning. The expressions of art and creativity and the respective institutions, through which it is produced, distributed and consumed. The contemporary use of computer and ICT in vocational education and training is one strand of local economic policy that could be used to cushion the negative effect of the painful transition from an industrial to a post industrial economy. In this model, ICT in vocational education and training is perceived in the language of economic, with the attendant measurement applied to policy analysis; investment, leverage, employment, direct and indirect income effects, social and spatial targeting etc. ICT in vocational education and training are situated in historical context and against a background of a rapidly globalizing world, the process of learning becomes significantly richer as students/teachers have access to new types of information and the new way this information can be manipulated by means of computational tools.

In the classroom, computer can be used for drill and practice, tutorials, games and simulations. Computer is useful in analyzing research data, for managing learning and other vocational education and training activities. They create rooms for interactive teaching and learning process with various microcomputer systems incorporating various software packages which are flexible and maximize learner's control. The students are taught the skill needed to perform a specific job. 
Increase in the technology usage in the working life and rapid technological developments have made technology usage necessary in the vocational education and training schools preparing individuals for the work life as well as other educational fields. Indeed, computer self-efficacy is one of the factors affecting the student's adaptation to the technology integration process. Hence, each learner has different interpretation to a phenomenon depending on some variables such as sex, age, education, economic, social or cultural factors. According to Dike (2002), ICT in vocational education and training can be described as being useful to:

- a systematic arrangement of instruction in such a way that learning is facilitated

- help the learners to interact individually or in groups for learning to take place

- easy delivery of a lesson by the teacher

- help learners to learn at their own pace and place

- help learners to learn faster and better

- broaden students' knowledge and level of understanding

The use of computer and ICT on vocational education and training allow countries to improve their educational systems in certain ways such as enabling societies to increase computer awareness and to learn about computers as instruments to meet social needs; using computers to train the various computers related skills as demanded by countries' respective levels of economic and technological development; employing computers as tools to help improve the quality of general education, particularly in critical areas where developing countries lack sufficient teachers and school facilities. As research seems to indicate (Fuller 1987), schools can be more effective in teaching knowledge that is more foreign to indigenous communities, particularly the use of computer simulations to replace expensive equipment in vocational education and training schools can also be a cost effective application.

Indeed, globalization has generated new necessities, ideologies, methods, and ways to understand communications. ICT is crucial for all governments in the world towards promoting equity. ICT has been considered a low cost opportunity towards equalizing educational systems. There are four pillars of education on vocational education and training through ICT: hardware and software, access to internet, competencies and skills, and content of the material (Magyar, 2004). Raising the level of low achievers is crucial for all countries if they aim at raising all students' educational achievement since the potential gains are greater for those students in any educational system (Sweet \& Meates, 2004). The widespread access to ICT in the past decade increased hopes for improving student learning (OECD, 2001). ICT connects information, products, people, ideas, individuals as well as communities globally at a relatively low cost. All countries, including OECD members, stress the importance of preparation of younger generations with ICT skills in their education policy documents. ICT brings new structures in learning. More so, ICT skills are needed in today's world.

\section{Implications of ICT on Vocational Education and Training}

ICT on vocational education and training is so important with its developmental implications that no country can afford to abandon completely efforts to diffuse this technology within its sociocultural structure. As Ogunsola (2005) stated that the diffusion of ICT into Africa is at a snail speed. 
This could be to the fact that learners may not have access to a computer either at work place or at home as well as poor electricity supply in Nigeria. The problem of ICT on vocational education and training in Nigeria hinges on funding, staffing, and management. Nigeria is still in search of adequate solutions to these problem areas. There is the realization that this type of education is capital intensive and that Government alone cannot bear its funding. Yet it has not been possible to obtain significant cooperation in funding from the private business who utilizes the products from vocational education. Nevertheless, efforts are on to generate the teaching staff for vocational education and training schools using local tertiary institutions that have the requisite training capacity. Also, the use of computer simulations to replace expensive equipment in vocational/technical schools can be a cost effective application.

The nation must design clear strategy for technological development and transfer of technology to suit its own field of vocational education and training. Careful labor market and cost benefit analysis must be undertaken, and in some cases they might reveal that other proven technologies are providing necessary textbooks, peer tutoring, training, supervision, and quality of teachers and distance learning (Parraton, 1982). Invariably effective policies should include criteria of selectivity cum flexibility, appropriate strategies for software development, and adequate organizational support, especially teacher participation. The implications of computer and ICT on education for the advancement of vocational education and training compel support and acceptance. The environment of rapid change is demanding higher priority to human resource development. In view of the above, we are at present, incurring conflicts between the economic interests of industrialized countries and political concerns of developing countries, and these conflicts appear to be intensifying as time goes on. Globalism and neo-globalism are advancing. Their implications in developing countries are legion. One important issue to note is that with their rapid pace and the more they grow and expand, the less accommodating globalized corporations and economic interests are likely to be towards governments and their specific political needs.

The integration of ICT into vocational education and training is a complex process. On the other hand it is necessary to determine the country's technology readiness level. Moreover the factors affecting an efficient technology implementation should be analyzed and searched out. It has been thought that studies on this subject provide necessary data in order to draw a roadmap for designing technology-rich learning system in vocational education and training. ICTs were reported as a predictor of economic growth and job creation (Campbell, 2001).

\section{Conclusion and Recommendations}

Many arguments support the integration of computer and ICT to change our educational practices in vocational education and training schools. The arguments in favor of introducing computers and ICT as instruments of change fall into three categories: epistemological, social, and economic. Some argue that computers represent a new learning paradigm. However, the issue remains that computer and ICT can only be meaningfully introduced in developing countries like Nigeria if they can be justified on both costs and effectiveness grounds. In the context of the above mission of vocational education and training, the domestic industrial production which scarcely meets the ever expanding domestic demand will grossly reduce. The result that the country remains largely as a high importer and consumer of foreign goods shall be a thing of the past. The concern for 
industrialization can only be achieved if skill development is encouraged through provision of adequate computer and ICT facilities in teaching and learning of vocational education and training in schools. These facilities will in turn equip the learners through interaction, the learners will equip the society through demonstration of the acquired skills in promoting local production and finally the society will equip the nation with the desired manpower.

The issue here is that the country have several needs for and reasons to design and implement viable computer and ICT education policies for VET. Such policies may consist of some comprehensive national plans or guidelines or they may refer to specific programs, for example, college and graduate level specialized programs and special incentives for schools to buy national equipment. Government should regulate the acceptance or acquisition of foreign hardware. Teachers are worried about hardware incompatibility for many hardware manufacturers are competing with one another. Special funds should be created for research and innovation. In many cases where formal policies do not exist, marginal and even underground entrepreneurial initiatives in both the public and private schools already exist. It is essential, however, that policies and incentives are put in place to ensure that basic needs are met, that some focus exists to maximize the return of investments, and that evaluation and experimentation is simultaneously undertaken to guarantee that lessons are learned and fed back to improve the policy and incentive mechanisms.

Given scarce resources, hard choices have to be based on a country's commitment to a given concept of computer literacy and education. Other countries' experience and the past history of introducing media in education can help developing countries avoid some mistakes and explore more effective policies. Even if it were desirable, it would be naive to expect countries to control every initiative in this field. Laissez-faire policies, however, are likely to be inefficient and expensive. Comprehensive attempts to universalize computer education at all levels will not go beyond official rhetoric.

At the same time, an increase in the number of teachers and sufficient installation of facilities and equipment for the vocational education and training classes were suggested. As well as to promote the establishment of new courses to merge information technology with processing courses to respond to the various needs for R\&D, applications, and maintenance of hardware and software (e.g. Information design courses, information communication courses, etc.). Computers, whether conceived as a tool to improve the quality of teaching or as direct tools for learning in school environments, need adequate organizational support, in terms of equipment, facilities, maintenance, installations, easy access to information, software, and updating. Training and incentives are also necessary to make the innovation succeed.

It appears reasonable to conclude that teachers would benefit from workshops and professional development programs focused upon the use of computers and ICT in teaching and learning of vocational education and training courses in schools. Bauer and Kenton (2005) suggest that teachers receive ICT instruction, that schools integrate computers and ICT into the curriculum, that schools provide the hardware and software needed to do so, and that the use of computers and ICT becomes an essential component of teacher preparation programs. 


\section{References}

Anderson, J. \& Van Weert, T. (2002). Information and communication technology in education: A curriculum for schools and programs of teacher development. Paris: UNESCO.

Bauer, J. \& Kenton, J. (2005). Toward technology integration in the schools: Why it isn't happening. Journal of Technology and Teacher Education, 13(4), 519-546.

Bennett, F. (2002). The future of computer technology in K-12 education. Phi Delta Kappan, 83(8), 621-626.

Campbell, D. (2001). Can the digital divide be contained? The digital divide: Employment and development implications. International Labour Review, 140(2), 119-141.

Dieuzeide, H. (1986). Reinventer la technologie de I' education. International Review of Education. XXXII, 285-293.

Dike, H. I. (2002). Alternative teaching approaches for social studies -With implications for social science and sciences. Port Harcourt. CAPIIC.

Federal Ministry of Education. (1996). The development of education 1994-1996. National report of Nigeria. International Conference on Education. 45th session, Geneva.

Federal Ministry of Education. (1999). Education For All 2000 Assessment: Country report of Nigeria. (Under the co-ordination of M.O.A. Olorunfunmi). Abuja.

Fuller, B. (1987). What school factors raise achievement in the third world? Review of Educational Research, 37(3), 255-292

IES-National Center for Education Statistics-Institute of Education Sciences. (2006). Computer and use by students in 2003. Statistical Analysis Report. Washington, DC: U.S, Department of Education (2006-5651).

Magyar, B. (2004). Real walls down, virtual walls up? In A. Karpati (Ed), Promoting equity through ICT in education: Project, problems, prospects. Budapest, Hungary: OECD and Hungarian Ministry of Education.

Ogunsola, L. A. (2005). Information and communication technologies and the effects of globalization: Twenty -first century 'digital slavery' for developing countries. Myth or Reality. Electronic Journal of Academic and Special Librarianship, 6(1-2).

Oguzor, N. S., Adebola, H. E., Opara, J. A. \& Eziefula, J. F. (2010). Information and communication technology (ICT): Its role and value in adult education in Nigeria. Proceedings of the 10th International Educational Technology Conference and Exhibition, 2, 805.

OECD. (1986). New information technologies: A challenge for education. Paris: OECD.

OECD. (2001). Learning to change: ICT in schools. Paris: OECD

Oliveira, J. B. (1986). Computers for education in developing countries: Facing hard choices. Washington, DC: Economic Development Institute.

Orivel, F. (1987). L'Introduction de la Micro-Informatique a I'Ecole Primaire en France: Premiers Elements d'Evaluation. Paper presented at the V1th World Congress of Comparative Education. Rio de Jeneiro, Brazil. 
Parraton. H. (1982). Alternative Routes to Formal Education-Distance Teaching for School Equivalency. Baltimore and London: John Hopkins University Press.

Porter, M. (1990). The competitive advantage of nations. London: Macmillan.

Ruberti, M. (1993). Guidelines for community action in the field of education and training. European Commission working paper (Unpublished). Brussels, Belgium.

Sweet, R. \& Meates, A. (2004). ICT and low achievers: What does PISA tell us? In A. Karpati (Ed), Promoting equity through ICT in education: Project, problems, prospects. Budapest, Hungary: OECD and Hungarian Ministry of Education.

UNESCO (2009). Information and communication technologies. Retrieved 30 August 2009 from http://www.unesco.org/es/higher-education/themes/ education-building-blocks/teachereducation/icts/

Correspondence: Nkasiobi Silas Oguzor, School of Vocational Education (Technical), Federal College of Education, Omuku, Nigeria. 